Article

\title{
Learning Ethical, Environmental and Professional Responsibility at Universitat Politècnica de València. Where Are We?
}

\author{
Ester Gimenez-Carbo ${ }^{1, *}$, María Esther Gómez-Martín ${ }^{1} \mathbb{D}$, Ernesto Fenollosa ${ }^{2} \mathbb{D}$, Marta Cabedo-Fabrés ${ }^{3}$, \\ Eloína Coll-Aliaga ${ }^{4}$, Ignacio Andrés-Doménech ${ }^{1}$ (D), María-Teresa Sebastiá-Frasquet ${ }^{5}$ (D), Maria Vargas ${ }^{6}$ (D), \\ Nuria Pascual-Seva ${ }^{6} \mathbb{D}$, Alicia LLorca-Ponce ${ }^{2}$, José Félix Lozano ${ }^{7} \mathbb{D}$ and Antonio Martí-Campoy ${ }^{8}$ (D)
}

1 Escuela Técnica Superior de Ingeniería de Caminos, Canales y Puertos, Universitat Politècnica de València, 46022 València, Spain; mgomar00@upv.es (M.E.G.-M.); igando@hma.upv.es (I.A.-D.)

2 Escuela Técnica Superior de Arquitectura, Universitat Politècnica de València, 46022 València, Spain; efenollo@mes.upv.es (E.F.); allopon@omp.upv.es (A.L.-P.)

3 Escuela Técnica Superior de Ingeniería de Telecomunicación, Universitat Politècnica de València, 46022 València, Spain; marcafab@dcom.upv.es

4 Escuela Técnica Superior de Ingeniería Geodésica, Cartográfica y Topográfica,

check for

updates

Citation: Gimenez-Carbo, E.; Gómez-Martín, M.E.; Fenollosa, E.; Cabedo-Fabrés, M.; Coll-Aliaga, E.; Andrés-Doménech, I.; SebastiáFrasquet, M.-T.; Vargas, M.; Pascual-Seva, N.; LLorca-Ponce, A.; et al. Learning Ethical, Environmental and Professional Responsibility at Universitat Politècnica de València. Where Are We? Sustainability 2021, 13, 9991. https://doi.org/10.3390/ su13179991

Academic Editors: Fermin Sanchez-Carracedo, Jordi Segalàs Coral and Gemma Tejedor

Received: 30 June 2021

Accepted: 3 September 2021

Published: 6 September 2021

Publisher's Note: MDPI stays neutral with regard to jurisdictional claims in published maps and institutional affiliations.

Copyright: (c) 2021 by the authors. Licensee MDPI, Basel, Switzerland. This article is an open access article distributed under the terms and conditions of the Creative Commons Attribution (CC BY) license (https:// creativecommons.org/licenses/by/ $4.0 /)$.
Universitat Politècnica de València, 46022 València, Spain; ecoll@cgf.upv.es

5 Escuela Politécnica Superior de Gandia, Universitat Politècnica de València, Calle Paranimf 1, 46730 Gandia, Spain; mtsebastia@hma.upv.es

6 Escuela Técnica Superior de Ingeniería Agronómica y del Medio Natural, Universitat Politècnica de València, 46022 València, Spain; mavarco@tal.upv.es (M.V.); nupasse@prv.upv.es (N.P.-S.)

7 Escuela Técnica Superior de Ingeniería Industrial, Universitat Politècnica de València, 46022 València, Spain; jlozan@dpi.upv.es

8 Escuela Técnica Superior de Ingeniería Informática, Universitat Politècnica de València, 46022 València, Spain; amarti@disca.upv.es

* Correspondence: esgimen@cst.upv.es

Abstract: This paper presents a study on the development of the cross-curricular learning outcome (CCLO) "Ethical, environmental and professional responsibility" for students of different Bachelor's Degrees taught at Universitat Politècnica de València (Spain). The work involved in the development of this learning outcome entails great complexity, given the double dimension of responsibility that it involves. At the end of their training at the university, students are expected to show ethical, environmental, and professional responsibility towards themselves and others. Interviews have been conducted with lecturers who work and assess this outcome in their subjects, most/all of them related to science and engineering. The objective was to identify the learning approach used in the different subjects to guarantee the acquisition of this CCLO by the students. A focus group has also been carried out with students to determine the importance they give to this learning outcome, and to know their degree of satisfaction with the training received. The methodology used to obtain the data from lecturers and students and to process the information to get a precise diagnosis is fully described in the paper. Results are satisfactory to some extent: most of the lecturers carry out appropriate activities and most students achieve the expected proficiency level. Finally, recommendations are given to improve the development of this cross-curricular learning outcome.

Keywords: cross-curricular learning outcome; ethical responsibility; environmental responsibility

\section{Introduction}

The training and assessment of our students in Cross-Curricular Learning Outcomes (CCLO) is a complex problem and, although there is consensus on their importance, there is still not a clear idea on how to implement these competences in the curricula and how to assess them [1]. 
When we talk about CCLO, we are referring to a series of learning outcomes that all students, regardless of their university studies, must acquire, without a specific subject in the educational program dedicated exclusively to learning them.

Some of these CCLOs have been encompassed in terms such as sustainability learning outcomes; several studies show how they are achieved, what methodologies are used (case studies, lectures, project-based learning, service-learning, etc.) to ensure that future professionals develop their work with this knowledge [2-4].

Other studies highlight that teaching and the educational program quality are not the only important determinants of students' learning outcomes [5]. It is very important and appropriate for universities to consider these outcomes, but other interactive, social and collaborative aspects are also determinant and will influence the results that graduates will obtain. In this sense, it is interesting that universities begin to measure these cross-curricular contributions and integrate them into their educational programs.

Accreditation agencies such as ABET [6] are also coming into play, introducing some of these CCLOs (i.e., an ability to recognize ethical and professional responsibilities in engineering situations and make informed judgments, which must consider the impact of engineering solutions in global, economic, environmental, and societal contexts) as essential elements that students must achieve by the end of their studies. The inclusion of these CCLOs within the curricula are mandatory for achieving a positive accreditation from these quality agencies. This fact, together with the growing importance and demand of society, has led to the study of the best way to incorporate these aspects into different fields of study related to business $[7,8]$ computer science $[9,10]$, and engineering [11,12].

Examples of several methodologies can be found in the literature [13-15], including how to integrate CCLOs across the curriculum [16-18], but we are still far from reaching a consensus on which is the best method, and we are not even sure of the results achieved by our students.

In this paper, we analyze the degree of acquisition of the CCLO "Ethical, environmental and professional responsibility" by the students of different bachelor's Degrees taught at Universitat Politècnica de València (UPV). Figure 1 shows the Gandia and Vera campuses and the schools participating in the project.

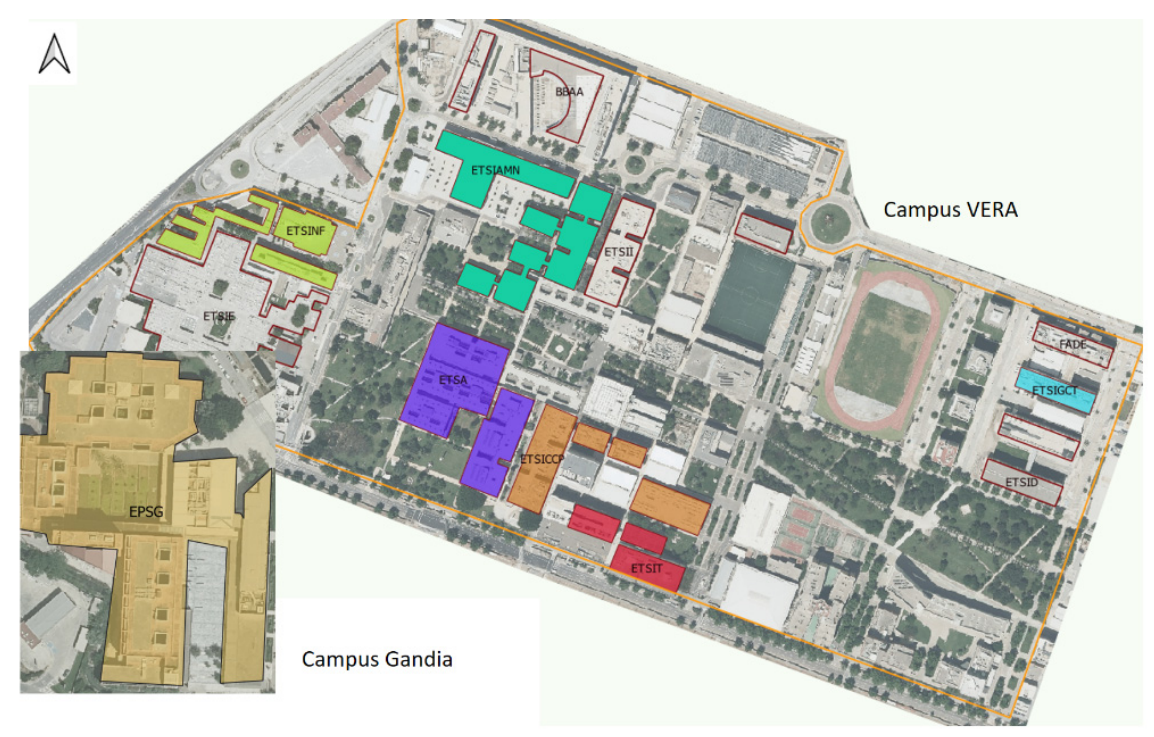

Figure 1. Schools participating in the project. Source: Prepared by the authors.

This CCLO is nowadays of the utmost importance; it is the basis for development of the social responsibility that future professionals will need to deal with the Sustainable Development Goals (SDGs) within the United Nations 2030 Agenda. However, how does UPV develop this ethical, environmental and professional responsibility? Are students acquiring this skill properly? How do lecturers feel about the way they teach and assess 
this CCLO? Before answering these questions let us review the way in which UPV has introduced these CCLOs within its bachelor's and master's degrees since 2015, and the way in which we assess whether our students achieve them.

\subsection{Development and Assesment of CCLOs at UPV}

In 2015, UPV launched an innovative institutional project with the aim of enabling students to acquire the CCLOs needed to become professionals adequately prepared for the demands of the labor market. Thirteen UPV CCLOs were then defined and training for these CCLOs was considered from a wide perspective, connecting them with the full education cycle of each person, and addressing both undergraduate and postgraduate studies [19].

Hence, the UPV CCLOs correspond to skills that are key and transferable in relation to the wide variety of personal, social, academic, and employment contexts that graduates may encounter throughout their lives. In this sense, UPV CCLOs constitute a fundamental part of the professional and formative profile of UPV's Bachelor's and Master's degrees. UPV CCLOs deal with issues that include a set of cognitive and metacognitive skills, and instrumental and attitudinal knowledge that are of great value to the knowledge society.

The main objective of the UPV's institutional project, was to systematize and guarantee the acquisition of the UPV CCLOs in the training process of students using different complementary paths or strategies. Moreover, the project also addressed the design of systematic evaluation processes and strategies for the UPV CCLOs, that may consider both the individual results of each student and the aggregate information for analysis and improvement of the training programs.

Each degree has defined association matrices, in order to assign the training and evaluation of the different CCLOs to specific subjects of the training program. These association matrices are reviewed and updated every year. They can be considered a key factor in the system, as they allow the appropriate design of the curriculum, and constitute the basis for the evaluation process. Aggregate information of the degree of achievement of the CCLOs by students is generated every year for continuous improvement.

As explained before, in this work we focus on the subjects that train for and assess the CCLO "Ethical, environmental and professional responsibility" in different UPV Bachelor's degrees. However, in future work we plan to address and analyze other UPV CCLOs following a similar approach.

\subsection{CCLO Ethical, Environmental and Professional Responsibility}

At present, the UPV is rethinking its institutional project and it is often questioned as to whether the actual number of selected CCLOs is excessive. Indeed, such a number is far from mainstream for agencies such as ABET or ANECA, which tend to reduce and specify this type of learning outcome. However, without question, one of the CCLOs that should appear in the curricula of engineering studies is the "understanding of professional and ethical responsibility", as ABET requires in its 3.f criterion [6].

In addition, there have been many experiences in introducing ethics into the curriculum of different bachelor degrees in different universities worldwide [16,20-22], without conclusive results.

It is difficult to assess the achievement of this competence [23-25], especially in the way it is introduced at UPV, where the CCLO "Ethical, environmental and professional responsibility" is the only one that has different learning outcomes for each level of competence, splitting environmental responsibility from ethical and professional responsibility. It is possible to act in an environmentally respectful way, without considering the resolution of a moral dilemma (e.g., by carrying out correct waste management). Nevertheless, certain problems may arise where ethical and professional responsibility are required, without being related to the environment.

As we will show in the following sections, most of the control point subjects of this CCLO worked only on one of these two aspects of the competence. This is fully 
understandable as it is difficult to introduce activities related to both aspects of the CCLO, to assess them and to obtain evidence, as well as to develop the specific technical content within subjects with an average teaching load of 4.5 ECTS.

Therefore, the final objective of this work is not to evaluate the degree of achievement of the competence by students, but to find out whether all students who have completed a degree at the UPV have been trained and have worked on this competence in order to be able to achieve it.

Our analysis aims to set a starting point to find out the status of the CCLO "Ethical, environmental and professional responsibility" in several bachelor's degrees taught at the UPV, and to give recommendations, based on our experience, to other institutions interested in working with this CCLO.

\subsection{Purpose of the Study}

The CCLO analyzed herein addresses two fundamental dimensions in the training of students: on the one hand, ethical and professional responsibility and, on the other, environmental responsibility. In addition, the scope of the CCLO, in each of its dimensions, is instrumentalized in two levels of proficiency. Therefore, the objective of this work is to determine to what extent the students who complete the analyzed bachelor's degrees at UPV have acquired this competence in each of its two dimensions. For this purpose, we will consider the following research questions:

- Is the CCLO sufficiently developed in the selected degrees? What is the level of development in each of them?

- What activities are designed and carried out so that students can acquire the competence? Are the activities oriented to achieve the two dimensions of this competence?

- What evaluation tools are used to verify that students have acquired the CCLO? Is it intended to know how each of the proficiency levels of the competence are evaluated?

- What is the perception of lecturers about the importance of the competence in the training of students? What problems do they identify in its implementation?

- What is the perception of the students about the means of acquisition of the competence, as well as its evaluation throughout their studies? Are there any differences in the development of the CCLO in the degrees studied?

\section{Materials and Methods}

Six out of thirteen schools (see Table 1) were selected to gather information about the number of subjects that train and assess students in the CCLO "Ethical, environmental and professional responsibility", and the appraisal of students and lecturers regarding this outcome.

Table 1. List of schools, Bachelor's Degrees and subjects considered. Source: Prepared by the authors based on the subjects' syllabi.

\begin{tabular}{|c|c|c|}
\hline Name of School & Grade & Subject \\
\hline $\begin{array}{c}\text { School of Agricultural Engineering and } \\
\text { Environment. } \\
\text { (ETSEAMN) }\end{array}$ & $\begin{array}{c}\text { Bachelor's Degree in Agricultural and } \\
\text { Biological Engineering. } \\
\text { (GIAMR) }\end{array}$ & $\begin{array}{c}\text { Geology, soil science and climatology. } \\
\text { Chemistry-Extension course. } \\
\text { General agronomy. } \\
\text { Crop protection. } \\
\text { Soil mechanics, foundations, and rural roads and paths. } \\
\text { Horticulture: vegetable crops. } \\
\text { Animal nutrition. } \\
\text { Sustainable agriculture. } \\
\text { Irrigation and fertilization needs and programming. }\end{array}$ \\
\hline
\end{tabular}


Table 1. Cont.

\begin{tabular}{|c|c|c|}
\hline Name of School & Grade & Subject \\
\hline $\begin{array}{l}\text { School of Architecture. } \\
\text { (ETSA) }\end{array}$ & $\begin{array}{c}\text { Bachelor's Degree in the Fundamentals } \\
\text { of Architecture. } \\
\text { (GFA) }\end{array}$ & $\begin{array}{l}\text { Introduction to architectural construction. } \\
\text { Physics for environmental conditioning. } \\
\text { Electrical installation systems. } \\
\text { Sustainable development. } \\
\text { Architectural, city and landscape project. Sustainable } \\
\text { habitat. } \\
\text { Projects } 2 . \\
\text { Projects } 3 . \\
\text { Projects } 5 . \\
\text { Bachelor's thesis. }\end{array}$ \\
\hline $\begin{array}{l}\text { School of Civil Engineering. } \\
\text { (ETSECCP) }\end{array}$ & $\begin{array}{l}\text { Bachelor's Degree in Civil Engineering. } \\
\text { (GIC) }\end{array}$ & $\begin{array}{l}\text { Topography. } \\
\text { Science and environmental impact of civil engineering. } \\
\text { Industrialized construction. } \\
\text { Construction management and organization. } \\
\text { Ethics in civil engineering. }\end{array}$ \\
\hline $\begin{array}{l}\text { Higher Polytechnic School of Gandia. } \\
\qquad \text { (EPSG) }\end{array}$ & $\begin{array}{l}\text { Bachelor's Degree in } \\
\text { Environmental Sciences. } \\
\text { (GCM) }\end{array}$ & $\begin{array}{l}\text { Society and environment. } \\
\text { Environmental law and public administration. } \\
\text { Environmental assessment and management. } \\
\text { Oceanography, dynamics, and coastal processes. } \\
\text { Renewable energies. }\end{array}$ \\
\hline $\begin{array}{c}\text { School of Engineering in Geodesy, } \\
\text { Cartography and Surveying. } \\
\text { (ETSEGCT) }\end{array}$ & $\begin{array}{c}\text { Bachelor's Degree in Geomatics and } \\
\text { Surveying Engineering. } \\
\text { (GIGT) }\end{array}$ & $\begin{array}{l}\text { Cartography. } \\
\text { Environmental engineering. } \\
\text { Business organization and management. } \\
\text { Cadastre. }\end{array}$ \\
\hline $\begin{array}{l}\text { School of Telecommunications } \\
\text { Engineering. } \\
\text { (ETSET) }\end{array}$ & $\begin{array}{c}\text { Bachelor's Degree in Telecommunication } \\
\text { Technologies and Services Engineering. } \\
\text { (GITST) }\end{array}$ & $\begin{array}{l}\text { Processing and energy conversion. } \\
\text { Acoustics. } \\
\text { Computer fundamentals. } \\
\text { Instrumentation and quality. } \\
\text { Mobile and wireless communications. }\end{array}$ \\
\hline
\end{tabular}

Data analyzed in this work come from four different sources: school administrations, official syllabi of subjects, individual interviews with lecturers and group meetings with students.

School administrations: each school administration was requested for the list of subjects allocated to assess the CCLO "Ethical, environmental and professional responsibility (CC07)", and the global assessment results for the last available academic year (18/19).

Official syllabi: All subjects taught at UPV publish their official syllabus on UPV's website. Members and non-members of UPV can access this information. The syllabus includes all the relevant information about the subject, such as learning outcomes, assessment plan, teaching methodologies, etc. The syllabus presents, in detail, the CCLO that will be assessed within the subject. This information comprises the activities the students will carry out and the way they will show their level of achievement. The syllabus of subjects involved in CC07 assessment were downloaded and analyzed. Activities and assessment criteria were extracted and compiled. Table 1 shows the subjects per Bachelor's Degree and school.

The syllabi were analyzed using the following questions and the possibly answers are shown in Table 2.

Interview with lecturers: A questionnaire was designed to obtain the point of view of the lecturers involved in training and assessing this CCLO. The questionnaire includes 11 open questions (or open-ended) that collect information about their difficulties, opinions and feelings. These questions, together with those answered by the students, were agreed after several meetings conducted by the authors under the supervision of an expert and after having reviewed the existing literature [26,27]. The questionnaire can be found in Table 3. First interviews were carried out face to face at the beginning of the academic year 2020, but the outbreak of COVID-19 pandemic in the second half of March suggested to the authors that they should carry out the interviews by email and video call. 
Table 2. Items used to analyze the syllabi. Source: Prepared by the authors.

\begin{tabular}{lll}
\hline \multicolumn{1}{c}{ Item } & \multicolumn{1}{c}{ Question } & \multicolumn{1}{c}{ Answers } \\
\hline Elective. & Is the subject compulsory? & No; Yes. \\
\hline Embedded. & $\begin{array}{l}\text { Are the activities carried out to train and assess the } \\
\text { CC07 strongly related to the specific competences } \\
\text { of the subject? }\end{array}$ & No; Low; Medium; High. \\
\hline Acquisition level. & Is the acquisition level (one or two) clearly stated? & No; Yes. \\
\hline Difficulty level. & $\begin{array}{l}\text { Is the difficulty of ideas and activities similar to the } \\
\text { difficulty of the subject? }\end{array}$ & Lower; Similar; Higher. \\
\hline Syllabus-Classroom link. & $\begin{array}{l}\text { Are the activities actually developed the same that } \\
\text { the ones described in the syllabus? }\end{array}$ & $\begin{array}{l}\text { No; Partially; Yes. This item was completed } \\
\text { after the interview with lecturers. }\end{array}$ \\
\hline Institutional rubric. & Is the UPV institutional rubric used? & No; Yes. \\
\hline Dimension. & Does the course cover both dimension of CC07? & $\begin{array}{l}\text { Yes; Only environmental; Only ethic and } \\
\text { professional. }\end{array}$ \\
\hline
\end{tabular}

Table 3. Questionnaires for lecturers. Source: Prepared by the authors.

\begin{tabular}{ll}
\hline & \multicolumn{1}{c}{ Questions } \\
\hline 1. My subject assesses CCO7 because (I chose, it was imposed, I don't know, ...). \\
2. Do you think CCO7 is relevant for this Bachelor's degree? \\
3. Was it easy to include/work CC07 within your subject? \\
4. Did you received help to develop this competence in the classroom? (staff training, guidance, examples, ...). \\
5. What do you think about the perception of students on this competence? Do they understand and think it is worth for their \\
6. Wrofessional career? \\
7. How do you assess this competence? \\
8. What do you think about the influence of this competence over students? Do you think students improve their awareness \\
9. How do you feel working on CC07? Is it an overload, an inconvenience? Alternatively, do you feel involved, satisfied, and \\
10. What are the main obstacles and troubles you faced? \\
11. Please, write any advice or proposal to improve the acquisition of this competence. \\
\hline
\end{tabular}

Group meeting with students: The sample size was 91 students with an age range of between 21-25 years. A homogeneous sample size was studied for each grade. The students were asked to participate voluntarily, with a maximum of 19 students per group. The objective was to have a representative sample willing to collaborate in the study. Recently LGBTQ activists and academics have advocated the use of non-binary gender categories in surveys to be respectful of the increasing number of people who do not place themselves into the two conventional classes (male, female) [28]. In our research, seeking differences among gender classes was not an objective, so we did not include gender information in the two questionnaires. Short meetings (less than $90 \mathrm{~min}$ ) were also performed. Most of the meetings were held face-to-face during the beginning of the academic year 2020, but some of the meetings that were planned for fall 2020 were held using on-line meeting platforms and forms (Microsoft Teams Suite). The students formed groups of four members and the planning of each meeting was as follows:

- Brief presentation (5 $\mathrm{min}$ ) of the institutional project of CCLO and the acquisition levels.

- Questionnaire 1 (Table 4) with five open questions on their knowledge and global feelings about the institutional project. Students answered the questions in an individual manner, and then discussed their answers within the group. Finally, all the groups exchanged ideas.

- A second presentation dealing with the list of subjects working with this CCLO within the educational program, the activities developed and the assessment criteria. 
- Questionnaire 2 (Table 4) with eight open questions regarding the activities that students remember having done in each subject, and their appreciation or their success in acquiring the competence. As in the first questionnaire, students answered in an individual manner, then discussed within their group and finally with all the other groups.

- The meeting finished with a general discussion where students are asked to propose improvements to the whole project, as well as for CC07 competences.

Table 4. Questionnaires for students. Source: Prepared by the authors.

\begin{tabular}{|c|c|c|}
\hline & & Questions \\
\hline \multirow{6}{*}{ Questionnaire 1} & 1. & Do you know the institutional project? \\
\hline & 2. & Do you know the acquisition levels for each CCLO? \\
\hline & 3. & Do you remember which subjects were an assessment point for \\
\hline & & this CCLO within the program curriculum? \\
\hline & 4. & $\begin{array}{l}\text { Do you understand the meaning of the different acquisition levels } \\
\text { to be achieved? }\end{array}$ \\
\hline & 5. & Do you think you have reached the expected acquisition levels? \\
\hline \multirow{8}{*}{ Questionnaire 2} & 1. & Are you aware that $\mathrm{CC} 07$ was evaluated in all these subjects? \\
\hline & 2. & $\begin{array}{l}\text { Are you aware that CCO7 was evaluated in some of these } \\
\text { subjects? }\end{array}$ \\
\hline & 3. & $\begin{array}{l}\text { Do you think that you reached the expected proficiency level } \\
\text { with the developed activities related to CC07? }\end{array}$ \\
\hline & 4. & $\begin{array}{l}\text { Considering all the information you got during the Bachelor's } \\
\text { degree, will you act ethically, environmentally and with } \\
\text { professional responsibility in your professional life? }\end{array}$ \\
\hline & 5. & Do you know your grade regarding CC07? Do you agree? \\
\hline & & $\begin{array}{l}\text { Do you think that training related to CCO7 must be increased in } \\
\text { the program curriculum? }\end{array}$ \\
\hline & 7. & In each subject, did you worked the CC07 before being assessed? \\
\hline & 8. & The learning and assessment of CC07 supposed and overload? \\
\hline
\end{tabular}

Analyses of variance (ANOVA; Statgraphics Centurion for Windows, Statistical Graphics Corp.) were run on the results of the students' questionnaires to determine differences between degrees, (sample size 91; degrees of freedom: 4). Mean separations were performed when appropriate, using the Fisher's least significance difference (LSD test) at $p=0.05$.

\section{Results}

\subsection{Data from School Administration}

At the end of each academic year, schools generate a management report with the main statistical indicators about the development of each bachelor's degree grade, including student achievement in CCLO. The grades range from $\mathrm{D}$ to $\mathrm{A}$, where $\mathrm{D}$ means not achieved and A represents the maximum acquisition of the outcome. The values show that half of students achieve a mark B when they finish their studies, and close to half obtain a mark A. Less than $15 \%$ of students fail in this outcome. The aggregated distribution of marks for the six Bachelor's degrees are: mark D 2.8\%; mark C 12.8\%; mark B 45.3\% and mark A 39.1\%.

Distribution of marks for each school are shown in Figure 2. In all the Bachelor's degrees, except GITST, the predominant grade is B, followed by A. It is remarkable that GITST has a wider distribution than other degrees, with a high percentage of D and C grades. It must be mentioned that, in GITST, students who did not submit their activities received a D mark, while in the other degrees they were qualified as absent, with no grade. 


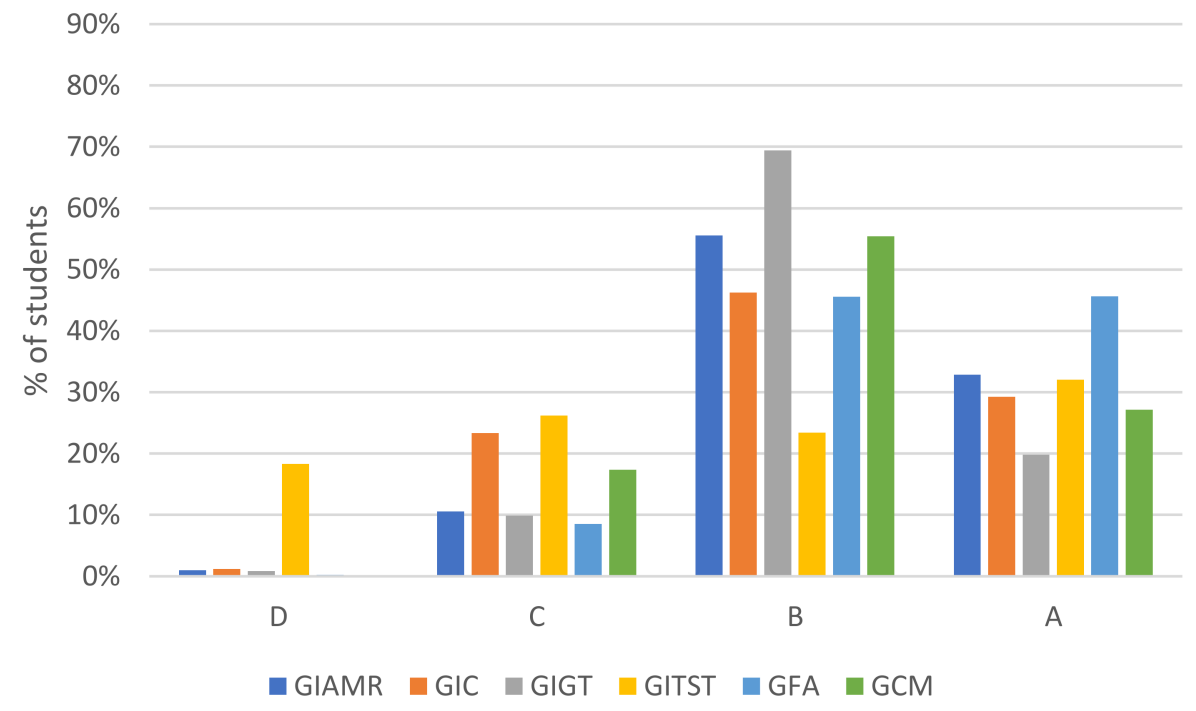

Figure 2. Distribution of grades in the different Bachelor's degrees. Grades: D (non-acquired), C (still progressing), B (correct) and A (excellent). Source: Prepared by the authors.

The CCLO Institutional project considers, for Bachelor's degrees, two acquisition levels. Level 1 is assessed at the end of the second year, and level 2 is assessed at the end of the fourth (and last) year. Figures 3 and 4 show the distribution of grades for each Bachelor's degree and each level. Although there are some differences, the trend in the distribution of grades is the same for both levels.

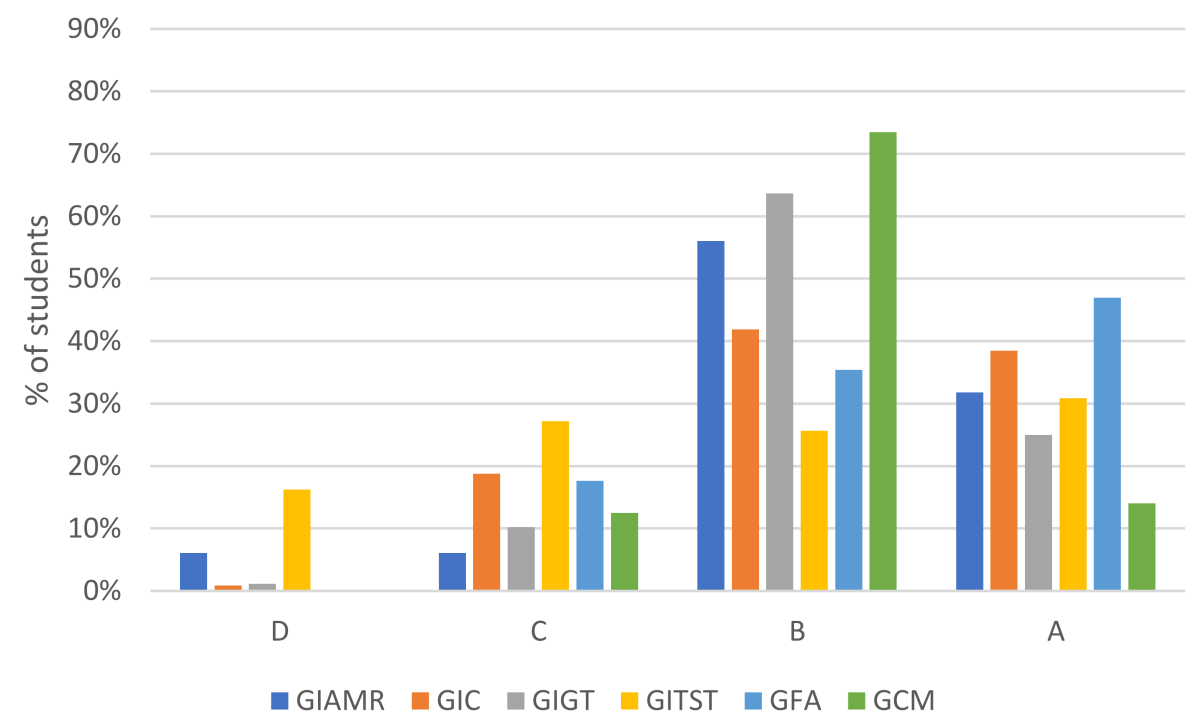

Figure 3. Distribution of grades obtained by the students in the different Bachelor's degrees (Level 1). Grades: D (non-acquired), C (still progressing), B (correct) and A (excellent). Source: Prepared by the authors. 


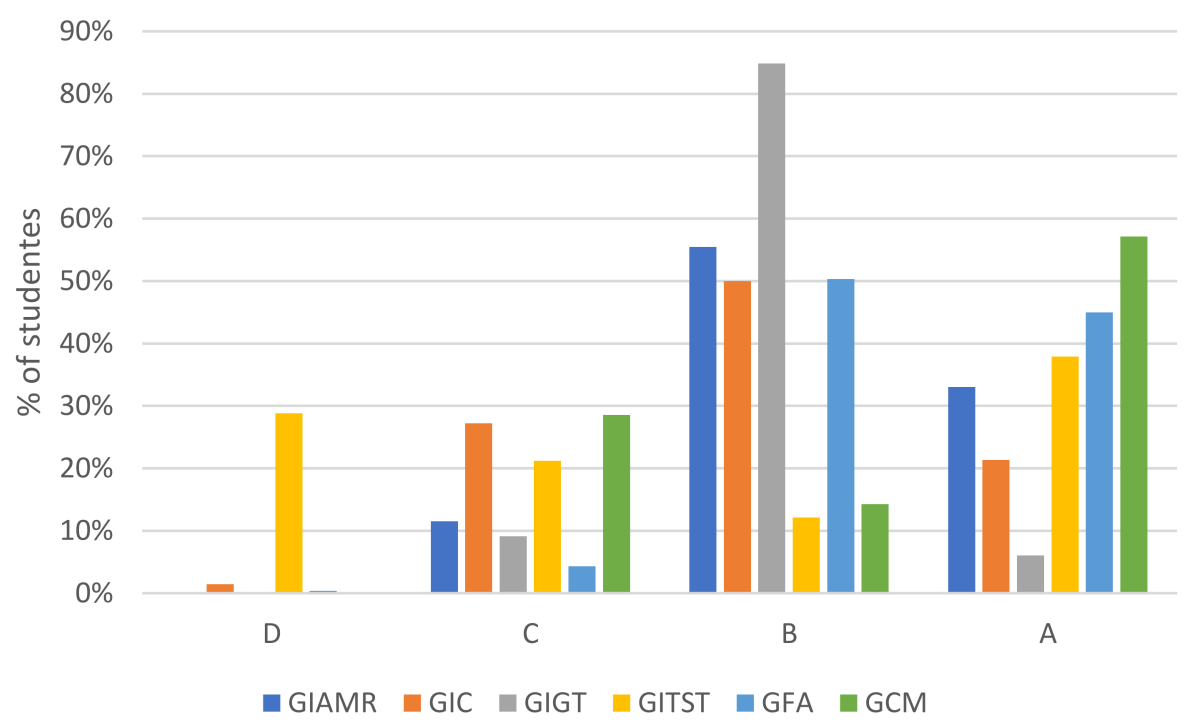

Figure 4. Distribution of grades obtained by the students in the different Bachelor's Degrees (Level 2). Grades: D (non-acquired), C (still progressing), B (correct) and A (excellent). Source: Prepared by the authors.

\subsection{Official Syllabus}

The scope of this work covers four Bachelor's degrees in engineering (GITST, GIAMR, GIC and GIGT), one in Architecture (GFA) and one in Sciences (GCM). The information described herein has been extracted from the official syllabi of the different subjects and it has been contrasted through personal interviews with lecturers responsible for each subject. Table 5 lists the subjects that assess the CCLO "Ethical, environmental and professional responsibility" in each Bachelor's Degree, their number of credits and whether one or both of the aspects of the CCLO are developed.

Table 5. Subjects that develop and evaluate the CCLO “Ethical, environmental, and professional responsibility". Source: Prepared by the authors.

\begin{tabular}{cccccccccc}
\hline \multirow{2}{*}{ Degree } & \multicolumn{3}{c}{ Number of Subjects } & \multicolumn{3}{c}{ Number of Credits } & \multicolumn{3}{c}{ Aspect } \\
\cline { 2 - 9 } & C & O & C+O & C & O & C+O & E & E/P & B \\
\hline GIAMR & 5 & 4 & 9 & 28.5 & 22.5 & 51.0 & 4 & 1 & 3 \\
GIC & 3 & 2 & 5 & 13.5 & 9.0 & 22.5 & 1 & 1 & 3 \\
GIGT & 4 & 0 & 4 & 20.5 & 0.0 & 20.5 & 3 & 0 & 1 \\
GITST & 3 & 2 & 5 & 13.5 & 12.0 & 25.5 & 0 & 3 & 2 \\
GFA & 6 & 2 & 8 & 61.5 & 9.0 & 70.5 & 3 & 0 & 5 \\
GCM & 3 & 2 & 5 & 24.0 & 9.0 & 33.0 & 4 & 0 & 1 \\
\hline
\end{tabular}

C: Compulsory subjects; O: elective subjects; B: Both aspects. E: Environmental aspect; E/P: Ethical and professional aspect.

There are several methods for developing and evaluating this outcome, including case studies or project work. Table 6 lists the different methods used and the number of subjects in which each method is applied. As can be observed, the use of rubrics for evaluation is not common, having no evidence of the use of institutional rubrics, and therefore there is no mention to the two acquisition levels. 
Table 6. Methodology used for developing the UPV CCLO "Ethical, environmental, and professional responsibility". Source: Prepared by the authors.

\begin{tabular}{|c|c|c|c|c|c|c|c|c|c|c|c|c|}
\hline \multirow{2}{*}{ Degree } & \multicolumn{10}{|c|}{ Methodology } & \multicolumn{2}{|c|}{ Evaluation } \\
\hline & $\mathrm{S}$ & PBL & C & $F$ & PS & $\mathbf{R}$ & G & $\mathrm{E}$ & $\mathbf{W}$ & $\mathbf{U}$ & $\mathbf{N}$ & RU \\
\hline GIAMR & 1 & 0 & 2 & 1 & 1 & 1 & 1 & 0 & 0 & 5 & 7 & 2 \\
\hline GIC & 1 & 0 & 0 & 2 & 0 & 0 & 1 & 1 & 0 & 2 & 5 & 2 \\
\hline GIGT & 1 & 0 & 2 & 1 & 0 & 0 & 1 & 1 & 0 & 1 & 3 & 1 \\
\hline GITST & 0 & 0 & 4 & 0 & 0 & 0 & 3 & 0 & 0 & 1 & 5 & $?$ \\
\hline GFA & 0 & 5 & 0 & 0 & 1 & 0 & 0 & 0 & 0 & 3 & 3 & 1 \\
\hline GCM & 0 & 1 & 2 & 1 & 1 & 0 & 0 & 0 & 1 & 2 & 3 & 0 \\
\hline
\end{tabular}

Methodologies (S: seminar; PBL: project-based learning; C: case; F: forum and debate; PS: problem solving; R: readings; G: gamification and simulation; E: external visits and field trips; W: written report; U: undefined) and evaluation description (N: number of subjects where it is described; RU: number of subjects where a rubric is used).

All Bachelor's degrees develop this CCLO in a number of subjects proportional to the total number of subjects in each educational program. However, if expressed in terms of credits (Figure 5), greater differences are observed. The case of GFA is noteworthy, where the outcome is developed and evaluated for $20.5 \%$ of the compulsory credits of the degree, while in other bachelor's degrees the outcome is treated in subjects that represent just over $5 \%$ of their credits.

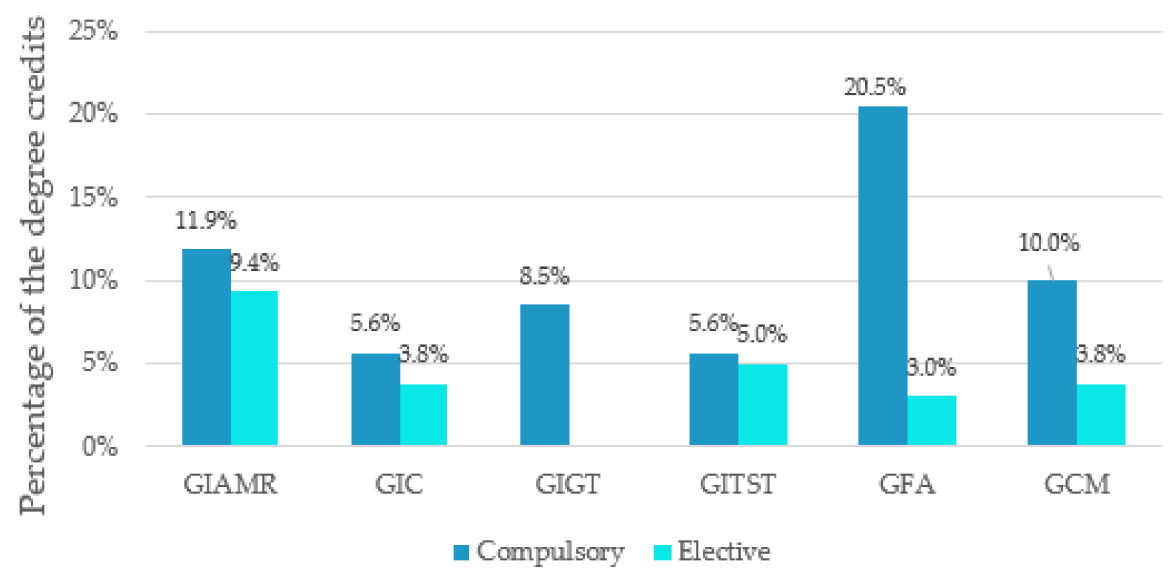

Figure 5. Proportion of credits (compulsory and elective) in which the UPV CCLO "Ethical, environmental, and professional responsibility" (CC07) is developed and evaluated in relation to each Bachelor degree. Source: Prepared by the authors.

The specific description of the activities to be carried out for the acquisition of the $\mathrm{CC} 07$ is uneven, with a high number of subjects detected $(27.45 \%)$ that do not describe them in detail. GITST stands out positively, where all subjects describe activities in a concrete way, while in GFA only half are described. Among the most common activities, one can mention the case study, used in $19.61 \%$ of subjects, followed by project-based learning and reading, both used in $11.76 \%$ of subjects (Figure 6). There is a very strong correlation between some methodologies and the particular Bachelor's degree. This is the case for project-based learning, which is used in five out of eight courses working this $\mathrm{CC} 07$ in GFA. However, this methodology is only used in one of the subjects of the other bachelor's degrees analyzed. 


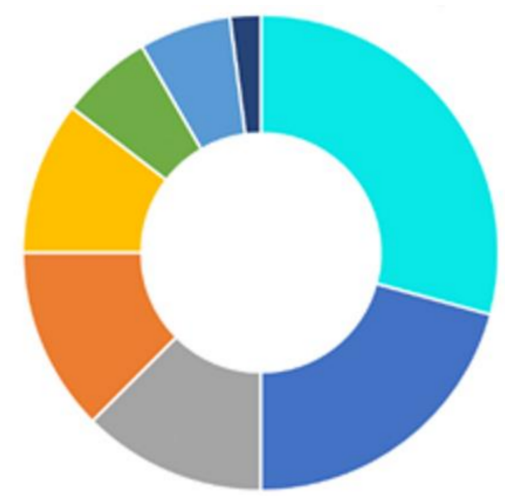

Undefined

Case study

Reading

PBL

Forums

Problem solving

Seminars

Figure 6. Methodologies used for developing the UPV cross-curricular outcome "Ethical, environmental, and professional responsibility" (CC07). Source: Prepared by the authors.

Overall, just over $43 \%$ of subjects develop both aspects involved in the outcome: environmental responsibility and ethics, and professional responsibility. Another 43\% work exclusively with the environmental aspects and $14 \%$ work only with the ethical and professional aspects of the CCLO (Figure 7).

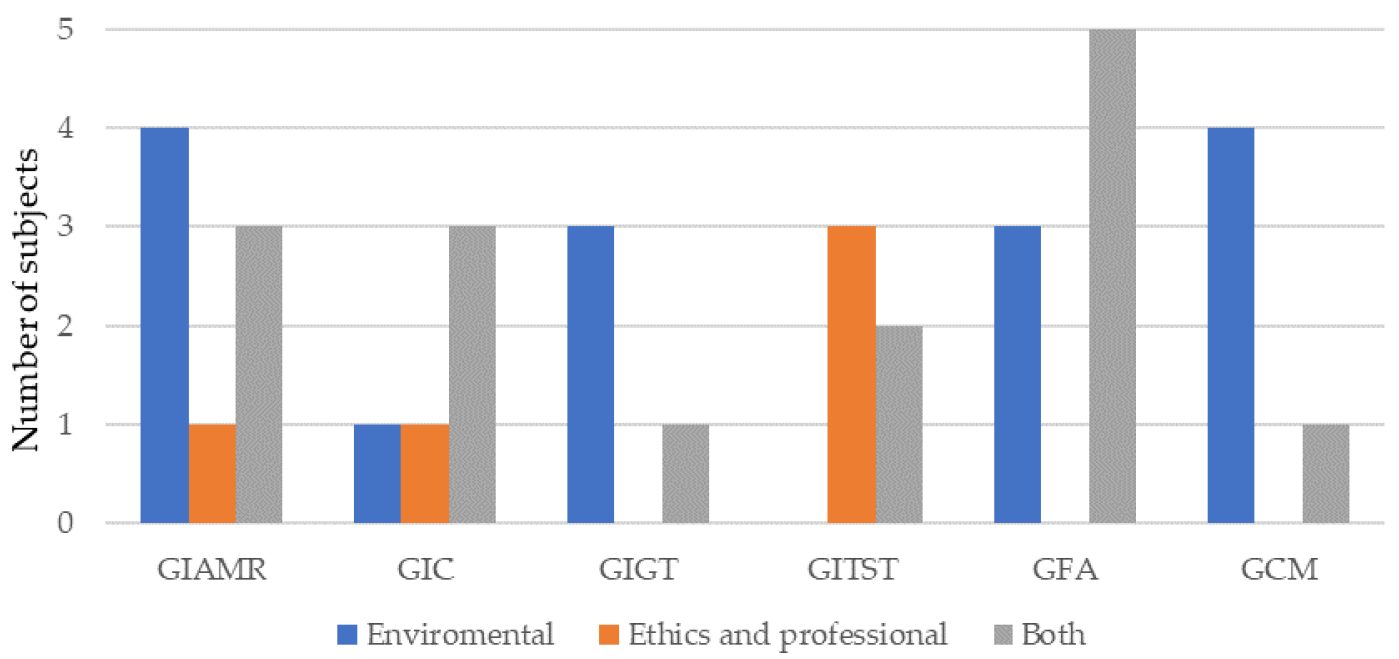

Figure 7. Number of subjects that develop and evaluate each aspect of the UPV CCLO "Ethical, environmental, and professional responsibility" (CC07). Source: Prepared by the authors.

Two Bachelor's degrees (GIGT and GCM) have no courses specifically working with the ethical and professional aspects and only one subject working with both aspects. Since the acquisition of the UPV CCLO is structured in two levels in the bachelor's Degrees, this fact shows that one of the two levels of the aforementioned aspects is not being developed within these degrees.

\subsection{Interviews with Lecturers}

Figure 8 presents the responses to the interviews with lecturers. Overall, it can be stated that virtually all lecturers (90\%) considered the CCLO "Ethical, environmental, and professional responsibility" as being relevant in the students' curriculum. The experience with this outcome is considered positive by $76 \%$ of the interviewees. This correlates with the fact that a similar percentage $(71 \%)$ of lecturers indicated that they chose to develop and evaluate this CCLO, or they agreed with the assignment made by the educational program manager. Less than $20 \%$ of the interviewed lectures had found any difficulty in working or evaluating this CCLO and around 33\% had required specific training in working with the outcome. Despite this positive predisposition to work with CC07, less 
than $40 \%$ of the lecturers considered that the outcome was having a positive impact on the students' learning.

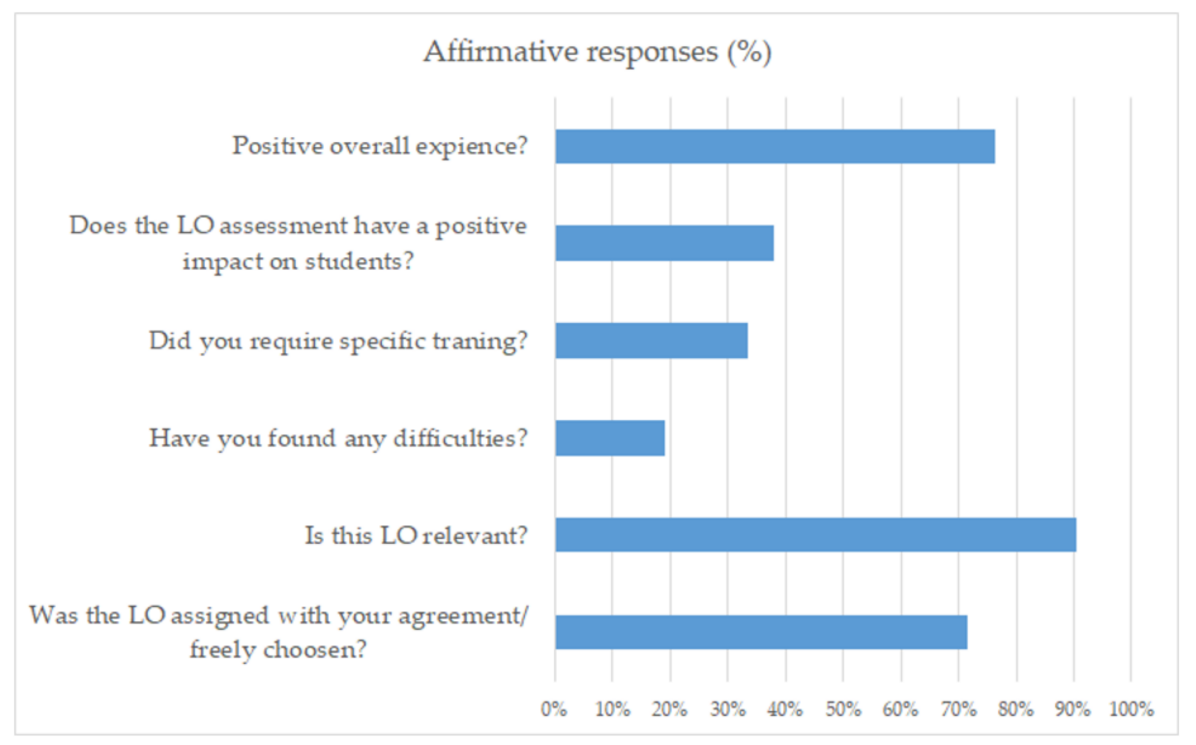

Figure 8. Lecturers' responses (presented as percentage of affirmative responses) to interviews regarding the UPV CCLO "Ethical, environmental, and professional responsibility" (CC07). Source: Prepared by the authors.

\subsection{Group Meeting with Students}

Figure 9 presents the response given by the students to the first questionnaire for each bachelor's degree. Most of the students (79\%) know about the UPV CCLO Institutional Project; GIGT students indicated a lower knowledge $(p \leq 0.05)$ than the other degrees, which did not otherwise show differences. However, that level of knowledge drops when related to acquisition levels, when only $44 \%$ of the interviewed students indicated that they knew the differences between the levels to be reached; the GIAMR students showed the highest knowledge $(p \leq 0.05)$ regarding this point. Once the meaning of the acquisition levels was re-explained to students, $91 \%$ stated that they understood them perfectly, with no statistical differences between degrees.

Students did not remember all the subjects in which they had been evaluated for this particular CCLO; only 25\% of the GITST remembered all of them. However, $62 \%$ of the students remembered at least one subject in which they had been evaluated, with no statistical differences among degrees. Only $70 \%$ of the interviewed students considered that they had reached the expected acquisition levels; all the GIGST students considered that they had reached the expected level, presenting a higher percentage $(p \leq 0.05)$ than the other degrees, with no statistical differences between them.

The students received a summary of the information related to the development of the outcome within each Bachelor's degree, and afterwards they answered a second questionnaire. The results are presented in Figure 10. Globally, 33\% of the students indicated that they were aware of being evaluated in all the subjects. The existing differences $(p \leq 0.05)$ between the evaluated bachelor's degrees is remarkable. While less than $10 \%$ of the GIC and GIGT students indicated that they were aware of this information, the percentage rose to values greater than $45 \%$ for the other degrees. When considering at least one subject, these percentages increased to $70 \%$ on average; higher values $(p \leq 0.05)$ were obtained in GCM, GIAMR and GITST than in GIC and GIGT. Regarding the knowledge of their marks, students showed great differences $(p \leq 0.05)$ between degrees. While $100 \%$ of the GIGST knew their qualifications, none of the GIC nor GCM acknowledged knowing theirs. 


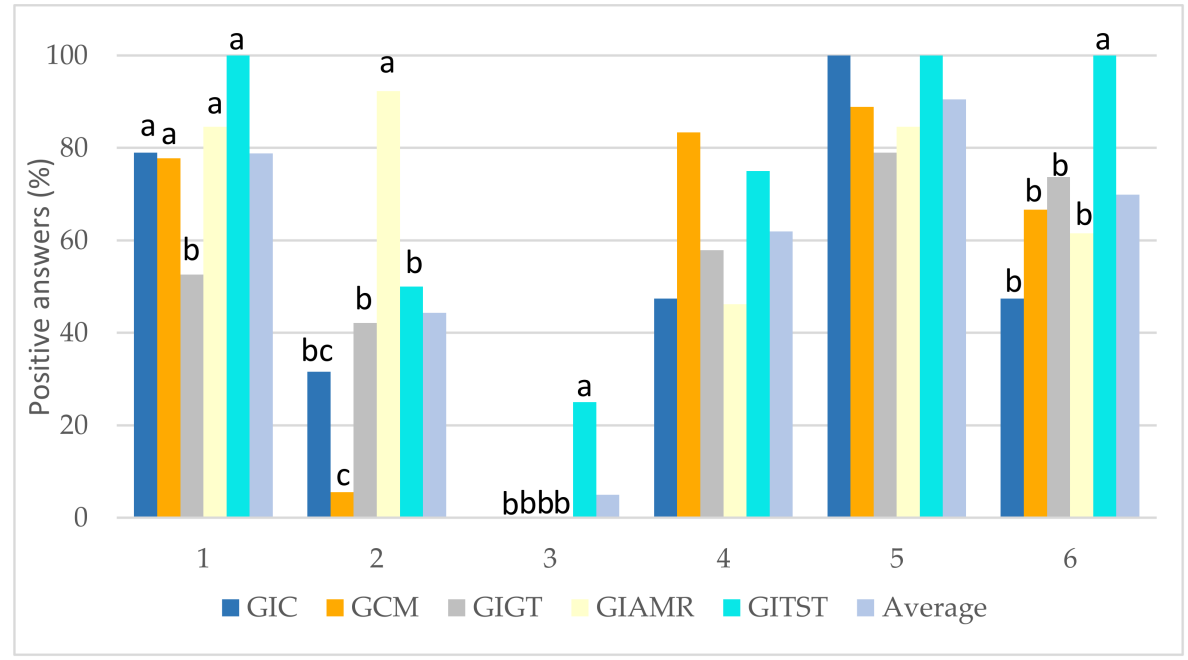

Figure 9. Students' response (presented as percentage of affirmative responses) to the UPV CCLO project questionnaire: project knowledge (1); knowledge of acquisition levels (2); remembered the subject where the generic outcome Ethical, environmental, and professional responsibility had been evaluated: all of them (3) and any of them (4); understanding of the acquisition levels (5); reaching the achievement levels (6). For each question, different letters above each column indicate significant differences $(p \leq 0.05)$ among degrees, ranging from a (maximum) to $c$ (minimum). The absence of a letter above the columns indicates that there are no significant differences $(p \leq 0.05)$ among degrees for the corresponding question. The corresponding F-ratio for each question is: 3.71, 8.09, 5.43, 2.13, 2.07 and 3.94. Source: Prepared by the authors.

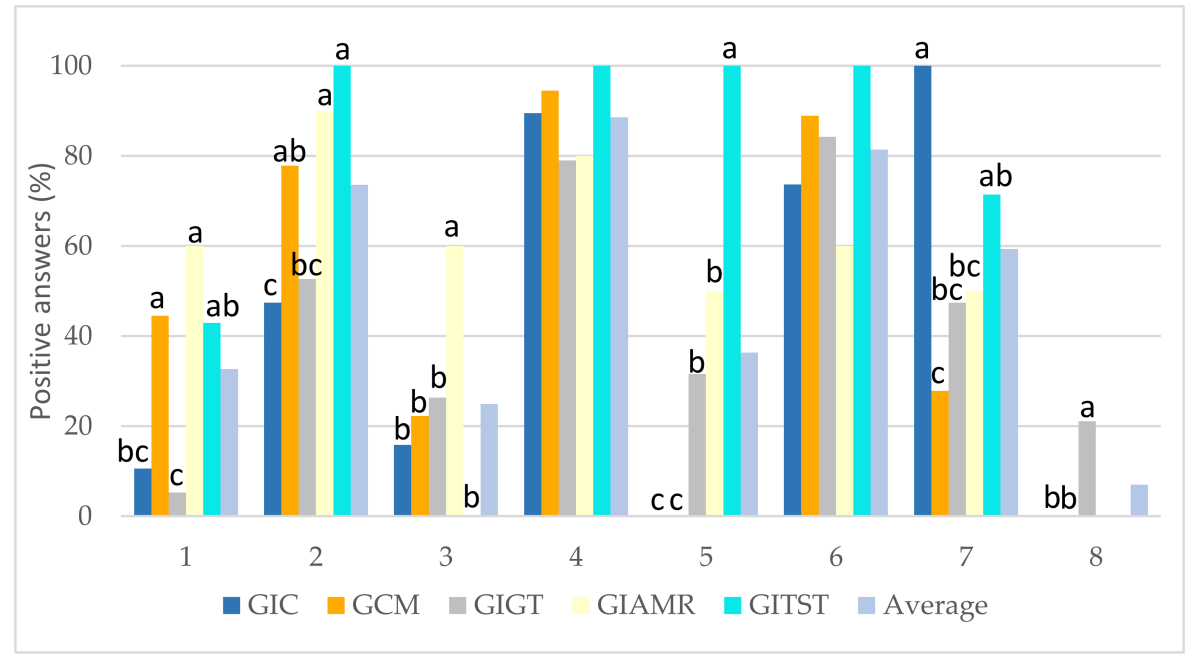

Figure 10. Students' responses (presented as percentage of affirmative responses) to the development of the outcome "Ethical, environmental, and professional responsibility" CC07 within each degree: awareness of being evaluated, in all the subjects (1) and in any subject (2); activities developed to help to reach the acquisition level (3); application of this responsibility in professional life (4); qualification knowledge (5), willingness to increase the development of this outcome in the curriculum (6); activities to develop the outcome prior to be evaluated (7); outcome development was supposed as an extra work overload (8). For each question, different letters above each column indicate significant differences $(p \leq 0.05)$ among degrees, ranging from a (maximum) to $c$ (minimum). The absence of a letter above the columns indicates that there are no significant differences $(p \leq 0.05)$ among degrees for the corresponding question. Questions 7 and 8 were not answered by the GIAMR and GITST students. The corresponding F-ratio for each question is: 4.85, 3.31, 2.67, 0.90, 17.90, 1.52, 7.47, 4.67. Source: Prepared by the authors. 
Close to $90 \%$ of the students believed that they will be able to apply the ethic, environmental and professional responsibility in their future jobs, with no statistical difference between degrees. Nevertheless, only $25 \%$ considered that they had achieved the CCLO thanks to the different activities developed along the subjects working with the competence; GIAMR students indicated a higher application of the activities developed than those from other degrees $(p \leq 0.05)$. Overall, $81 \%$ of the interviewed students considered that training related to this CCLO should be further considered in their respective educational programs, with no differences between degrees.

Nearly $60 \%$ of the students indicated that they had remembered to carry out different activities to develop the outcome before being evaluated, but, once again, there were differences $(p \leq 0.05)$ between bachelor's degrees, ranging from $28 \%$ in GCM to $100 \%$ in GIC. Only $21 \%$ of the GIGT students indicated that preparing for this generic outcome entailed a work overload.

\section{Discussion and Conclusions}

The work undergone within the six Bachelor's degrees at UPV has led to a diagnosis of the extent to which the institutional project on CCLO is performing after running for 6 years, specifically regarding the CCLO "Ethical, environmental and professional responsibility" (CC07). Official subject syllabi analysis, interviews with lecturers and focus groups with students were developed in order to assess, first, objective information but, further and even more relevant, the feelings and impressions of the two main actors in the teaching-learning process: lecturers and students.

UPV chose to integrate "Ethical, environmental and professional responsibility" learning in a transversal way into the educational program through a CCLO. Nevertheless, other universities include in their curricula compulsory subjects in this regard. There is no strong evidence on whether the method chosen at UPV is better than that chosen by other universities [29]. In one way or another, the objective of this work is to assess if we are achieving the expected results or if there are still barriers and difficulties hindering an effective deployment of the CCLO institutional project regarding CC07 learning at UPV.

The analysis of the different course syllabi involved in training for the CCLO highlights a high heterogeneity between schools and bachelor's degrees. First, the number of credits within the different educational programs that are devoted to CCLO is highly variable, but it is also important to note that, in some cases, a high proportion of these credits are elective, thus it is not assured that all students will follow the subject "Ethical, environmental and professional responsibility". There is also a great variety in teaching-learning methodologies. This is somehow expectable as these methodologies are mainly oriented towards the subject itself and to the development and assessment of the related technical competences. A paradigmatic example is the use of project-based learning methodologies in GFA.

Besides the above-mentioned heterogeneity, another point that arises when analyzing the different course syllabi is the double dimension of the "Ethical, environmental and professional responsibility" CCLO. Less than half of the analyzed courses develop both aspects of $\mathrm{CCO}$ (environmental, or professional and ethical responsibility). As a result, there is a risk of students not achieving some dimensions of the CCLO, especially if a high proportion of the subjects dealing with it are elective.

Regarding the activities developed to train and asses the CC07, most of the subjects carry out activities strongly related to the specific competences of the subject, with a similar degree of difficulty. Only some first-year subjects carry out activities with weak or no relationship with the matter the subject deals with.

The second target of the analysis was to interview lecturers. The main conclusion that arises is that a great majority recognizes that training in "Ethical, environmental and professional responsibility" is relevant and necessary within the students' curriculum. This result highlights that training our students to exercise their profession ethically and with environmental responsibility is a main priority along the educational programs. 
A paradoxical result emerges when lecturers are asked if they found any difficulties in working with the CCLO (less than $20 \%$ acknowledge difficulties) and if they required some training before tackling it (only 33\% recognize this need). It is surprising that staff training in ethics and professional and environmental responsibility is considered unnecessary by two out of three of the lecturers involved, although UPV offers, every year, specific training for lecturers on CCLOs. However, it is also remarkable that, in a university context, academic staff consider that is not necessary to be trained in ethics, which is a highly specific body of knowledge, that aims to guide human action in a rational sense: that is, it makes us act rationally [30]. As any other type of knowledge, ethics must be studied, learned, and understood. It is not enough to know the deontological codes of the different professions to teach "Ethical, environmental and professional responsibility". The foundations of this body of knowledge must be understood so lecturers' training is necessary for a successful implementation of the CCLO into the educational programs.

The third and last part of the analysis consisted of focus groups with students. The main objective of these focus group was to assess the level of achievement of the CCLO in the bachelor's degree. Many of the students interviewed knew the institutional program, even the CCLO, but this level of knowledge falls when asked for the meaning of the different levels of achievement. Nevertheless, a short explanation of this issue reverts this situation. This point highlights that it is of paramount importance to explain at the beginning of each subject the CCLO that will be offered, and to which extent, in order to clearly state the objectives aimed at and, how they will be assessed. Students should be trained in "Ethical, environmental and professional responsibility", which emphasizes the importance that lecturers had also received training.

A great majority of students have a high perception of the importance of exercising their professions ethically and with environmental and professional responsibility. Nevertheless, they do not acknowledge to have achieved this competence through the activities developed within the context of subjects dealing with the CCLO. Students demand a more effective and explicit training on "Ethical, environmental and professional responsibility" within their educational program.

Given this diagnosis, have we achieved the purposes of the institutional project regarding the "Ethical, environmental and professional responsibility" CCLO? Many authors have highlighted the importance of providing engineering students with an effective ethics education, and most engineering lecturers agree that ethics is an important aspect of engineering education [31]. However, there are still barriers hindering the effective integration of ethics into engineering, science and architecture educational programs: the curriculum is already full, and there is little room for ethics education; the faculty lacks adequate training for teaching ethics; there are too few incentives to incorporate ethics into the curriculum; policies on academic dishonesty are inconsistent; and institutional growth is taxing existing resources [32]. At least, the first three above mentioned obstacles exist at UPV. Best practices that allow for progress towards a better integration of the CCLO into the educational programs are fully applicable at UPV, which must be inspired by other successful experiences in order to improve its model. The main actions needed in the short term to improve the teaching-learning process of the $\mathrm{CC} 07$ are:

(a) Split the competence into two different areas, corresponding to the two present dimensions: environmental responsibility/ethical and professional responsibility.

(b) Emphasize the need to explain to students the institutional project, and, specifically, the scope of $\mathrm{CCO}$ and how it will be delivered and assessed.

(c) Highlight the importance of training for lecturers in the body of knowledge of ethics.

(d) Acknowledge the need for cross-coordination throughout the curriculum for a better integration of the CCLOs. The schools' boards and educational program managers must undergo this task.

(e) Consider the introduction of a compulsory subject within the educational program to develop the foundation of ethics. This will allow students to better develop the outcome in a multidisciplinary context within other technical subjects. 
The need for training in ethics and professional responsibility is, at present, essential for engineering and architecture bachelor's degrees in a worldwide context. In this sense, the Accreditation Board for Engineering and Technology (ABET) of the United States includes among outcomes to prepare graduates to enter the professional practice of engineering "an ability to recognize ethical and professional responsibilities in engineering situations and make informed judgments, which must consider the impact of engineering solutions in global, economic, environmental, and societal contexts". Students should achieve this outcome for exercising their profession successfully in a more critical and demanding societal context. After 6 years of implementation of the institutional project introducing CCLO into the educational programs, UPV must acknowledge some dysfunctions and overcome the identified difficulties for an effective introduction of "Ethical, environmental and professional responsibility" into its bachelor's degrees.

The conclusions of our analysis of CCLO implementation in the UPV, specifically $\mathrm{CC} 07$, highlight the key points that should be considered by other institutions planning to work with them. This type of project involves a high level of corporative coordination and the results presented here are very valuable as a starting point.

Author Contributions: Conceptualization, E.G.-C., M.E.G.-M. and I.A.-D.; methodology, J.F.L. and E.G.-C.; validation, N.P.-S., M.V., M.-T.S.-F., E.F. and A.M.-C.; formal analysis, E.C.-A., A.L.-P., M.V. and M.C.-F.; investigation, N.P.-S., I.A.-D. and A.M.-C.; resources, A.L.-P. and M.E.G.-M.; data curation, I.A.-D., N.P.-S. and A.M.-C.; writing-original draft preparation, E.G.-C., E.F., M.V. and A.M.-C.; writing-review and editing, I.A.-D.; visualization, A.L.-P., M.-T.S.-F. and E.C.-A..; supervision, J.F.L.; project administration, I.A.-D. and J.F.L.; funding acquisition, E.G.-C. All authors have read and agreed to the published version of the manuscript.

Funding: This innovative educational project and the APC of this paper were funded by Universitat Politècnica de València, through the project PIME/20-21/219 “Evaluación del nivel de adquisición de la CT07 Responsabilidad ética, medioambiental y profesional en los estudios de grado de la UPV. Propuestas de mejora".

Institutional Review Board Statement: Ethical review and approval for this study was waived due to the voluntary participation of those involved, and not to address ethics-related issues.

Informed Consent Statement: Informed consent was obtained from all subjects involved in the study.

Data Availability Statement: The data collected is stored at: https:/ / poliformat.upv.es/portal/site/ ICE_549_2019/tool/ee3e9ec0-acf8-49d8-b57f-ee19eb7da20c?panel=Main (accessed on 25 June 2021). They can also be requested from the corresponding author (available in Spanish).

Acknowledgments: Authors want to express their gratitude to lecturers responsible for the control point subjects, for their full collaboration and to students who participated in the group dynamics, for sharing their opinions and thoughts.

Conflicts of Interest: The authors declare no conflict of interest.

\section{References}

1. Martin, L.; Mahat, M. The Assessment of Learning Outcomes in Australia. AERA Open 2017, 3, 1-19. [CrossRef]

2. Bielefeldt, A.R. Pedagogies to achieve sustainability learning outcomes in civil and environmental engineering students. Sustainability 2013, 5, 4479-4501. [CrossRef]

3. Svanström, M.; Lozano-García, F.J.; Rowe, D. Learning outcomes for sustainable development in higher education. Int. J. Sustain. High. Educ. 2008, 9, 339-351. [CrossRef]

4. Jarchow, M.E.; Formisano, P.; Nordyke, S.; Sayre, M. Measuring longitudinal student performance on student learning outcomes in sustainability education. Int. J. Sustain. High. Educ. 2018, 19, 547-565. [CrossRef]

5. Smith, C.; Bath, D. The role of the learning community in the development of discipline knowledge and generic graduate outcomes. High. Educ. 2006, 51, 259-286. [CrossRef]

6. Accreditation Board of Engineering and Technology (ABET). Criteria for Accrediting Engineering Programs 2019-2020. Available online: https:/ / www.abet.org/accreditation/accreditation-criteria/criteria-for-accrediting-engineering-programs-2019-2020/ (accessed on 25 June 2021).

7. Fornes, G.; Monfort, A.; Ilie, C.; Koo, C.K.; Cardoza, G. Ethics, Responsibility, and Sustainability in MBAs. Understanding the Motivations for the Incorporation of ERS in Less Traditional Markets. Sustainability 2019, 11, 7060. [CrossRef] 
8. Setó-Pamies, D.; Papaoikonomou, E. A Multi-level Perspective for the Integration of Ethics, Corporate Social Responsibility and Sustainability (ECSRS) in Management Education. J. Bus. Ethics 2016, 136, 523-538. [CrossRef]

9. Casañ, M.J.; Alier, M.; Llorens, A. Teaching ethics and sustainability to informatics engineering students, an almost 30 years' experience. Sustainability 2020, 12, 5499. [CrossRef]

10. Rubio, R.M.; Uribe, D.; Moreno-Romero, A.; Yáñez, S. Embedding sustainability competences into engineering education. The case of informatics engineering and industrial engineering degree programs at Spanish universities. Sustainability 2019, 11, 5832. [CrossRef]

11. El-Zein, A.; Airey, D.; Bowden, P.; Clarkeburn, H. Sustainability and ethics as decision-making paradigms in engineering curricula. Int. J. Sustain. High. Educ. 2008, 9, 170-182. [CrossRef]

12. Wang, G.C.; Buckeridge, J.S.J.S. Teaching ethics for construction management majored students: Standalone or micro-insert?Globalization and sustainability considerations. In Proceedings of the 2016 ASEE Annual Conference and Exposition, New Orleans, LA, USA, 26-28 June 2016; American Society for Engineering Education-ASEE: New Orleans, LA, USA, 2016.

13. Miñano, R.; Uruburu, Á.; Moreno-Romero, A.; Pérez-López, D. Strategies for Teaching Professional Ethics to IT Engineering Degree Students and Evaluating the Result. Sci. Eng. Ethics 2017, 23, 263-286. [CrossRef]

14. Hsu, Y.C. An action research in critical thinking concept designed curriculum based on collaborative learning for engineering ethics course. Sustainability 2021, 13, 2621. [CrossRef]

15. Berdanier, C.G.P.; Tang, X.; Cox, M.F. Ethics and Sustainability in Global Contexts: Studying Engineering Student Perspectives Through Photoelicitation. J. Eng. Educ. 2018, 107, 238-262. [CrossRef]

16. Moore, C.; Hart, H.; Randall, D.; Nichols, S.P. PRiME: Integrating professional responsibility into the engineering curriculum. Sci. Eng. Ethics 2006, 12, 273-289. [CrossRef]

17. Glynn, E.; Falcone, F.; Doorley, M. Implementing ethics across engineering curricula. In Proceedings of the 2010 ASEE Annual Conference and Exposition, Louisville, KY, USA, 20-23 June 2010; American Society for Engineering Education-ASEE: Louisville, KY, USA, 2010; pp. 15.683.1-15.683.12.

18. Cruz, J.A.; Frey, W.J. An Effective Strategy for Integrating Ethics Across the Curriculum in Engineering: An ABET 2000 Challenge. Sci. Eng. Ethics 2003, 9, 543-568. [CrossRef] [PubMed]

19. UPV Cross-Curricular Learning Outcomes. Available online: http://www.upv.es/contenidos/COMPTRAN/info/957657 normalc.html (accessed on 25 June 2021).

20. Mitcham, C.; Englehardt, E.E. Ethics Across the Curriculum: Prospects for Broader (and Deeper) Teaching and Learning in Research and Engineering Ethics. Sci. Eng. Ethics 2019, 25, 1735-1762. [CrossRef]

21. Appel, F. Ethics across the computer science curriculum: Privacy modules in an introductory database course. Sci. Eng. Ethics 2005, 11, 635-644. [CrossRef] [PubMed]

22. Simonson, L. Introducing ethics across the curriculum at South Dakota School of Mines and Technology. Sci. Eng. Ethics 2005, 11, 655-658. [CrossRef]

23. Barry, B.E.; Ohland, M.W. ABET Criterion 3.f: How Much Curriculum Content is Enough? Sci. Eng. Ethics 2012, 18, 369-392. [CrossRef]

24. Selby, M.A. Assessing engineering ethics training. In Proceedings of the 2015 ASEE Annual Conference and Exposition, Seattle, WA, USA, 14-17 June 2015; American Society for Engineering Education-ASEE: Seattle, WA, USA, 2015; pp. 26.240.1-26.240.11.

25. Hess, J.L.; Fore, G. A Systematic Literature Review of US Engineering Ethics Interventions. Sci. Eng. Ethics 2018, 24, 551-583. [CrossRef]

26. Falcone, F.E.; Glynn, E.F.; Graham, M.E.; Doorley, M. Engineering ethics survey for faculty: An assessment tool. In Proceedings of the 2013 ASEE Annual Conference and Exposition, Atlanta, GA, USA, 23-26 June 2013; American Society for Engineering Education-ASEE: Atlanta, GA, USA, 2013; pp. 23.508.1-23.508.19.

27. Stephan, K.D. A Survey of Ethics-Related Instruction in U.S. Engineering Programs. J. Eng. Educ. 1999, 88, 459-464. [CrossRef]

28. Medeiros, M.; Forest, B.; Öhberg, P. The Case for Non-Binary Gender Questions in Surveys. PS Political Sci. Politics 2020, 53, 128-135. [CrossRef]

29. Barry, B.; Ohland, M. Engineering ethics curriculum incorporation methods and results from a nationally administered standardized examination: Background, literature, \& research methods. In Proceedings of the 2009 ASEE Annual Conference and Exposition, Austin, TX, USA, 14-17 June 2009; American Society for Engineering Education-ASEE: Austin, TX, USA, 2009; pp. 14.555.1-14.555.38. 
30. Cortina Orts, A. Ética de la Empresa: Claves Para una Nueva Cultura Empresarial, 5th ed.; Trotta: Madrid, Spain, 1994; ISBN 8481640131.

31. Unger, S.H. How best to inject ethics into an engineering curriculum with a required course. Int. J. Eng. Educ. 2005, 21, 373-377.

32. Walczak, K.; Finelli, C.; Holsapple, M.; Sutkus, J.; Harding, T.; Carpenter, D. Institutional obstacles to integrating ethics into the curriculum and strategies for overcoming them. In Proceedings of the 2010 ASEE Annual Conference and Exposition, Louisville, KY, USA, 20-23 June 2010; American Society for Engineering Education-ASEE: Louisville, KY, USA, 2010; pp. 15.749.1-15.749.14. 